O. Shutenko, S. Ponomarenko

\title{
ANALYSIS OF DISTRIBUTION LAWS OF TRANSFORMER OIL INDICATORS IN 110-330 kV TRANSFORMERS
}

Introduction. Ensuring the operational reliability of power transformers is an urgent task for the power industry in Ukraine and for most foreign countries. One of the ways to solve this problem is the correction of maximum permissible values of insulation parameters. However, such a correction is fundamentally impossible without an analysis of the laws of distribution of diagnostic indicators in the equipment with different states. The purpose of the research is to analyse the laws of distribution of the quality indicators of transformer oil with different states in 110 and $330 \mathrm{kV}$ transformers. Novelty. It was found that both $330 \mathrm{kV}$ autotransformers and $110 \mathrm{kV}$ transformers have the displacements between the mathematical expectations of the distribution density of usable oil indicators. It caused by different service life of the analysed transformers and different values of load factors. This indicates the need to consider the influence of these factors when correcting the maximum permissible values of oil indicators. Also, the presence of displacement between the distribution densities of some indicators of usable oil in $110 \mathrm{kV}$ transformers and $330 \mathrm{kV}$ autotransformers has been revealed. It indicates a different intensity of oxidation reactions in transformers with different voltage class. In order to reduce the heterogeneity of initial data the procedure of statistical processing of in-service test results has been proposed as a method. This procedure combines the use of a priori information about the service life of equipment and values of load factors with the elements of statistical hypothesis testing. The results of the analysis of the distribution laws of transformer oil indicators with different states have shown that for both usable and unusable oil the values of oil indicators obey the Weibull distribution. Values of the shape and scale parameters for each of the obtained indices arrays have been obtained, as well as calculated and critical values of the goodness-of-fit criteria. Practical value. Obtained values of the distribution law parameters of the transformer oil indicators with different states, considering the service life and operating conditions allow to perform the correction of the maximum permissible values of the indicators using the statistical decision-making methods. References 38, tables 7, figures 5 .

Key words: transformer oil, oil indicators, operating time, statistical analysis, distribution laws, goodness-of-fit criteria, Weibull distribution, density functions.

У статті наведено результати аналізу законів розподілу показників трансформаторних масел у трансформаторах $110 i$ 330 кВ. Встановлено, щзо розподіл показників для масла як придатного, так і непридатного до експлуатації, незалежно від класу напруги трансформаторів підпорядковуються закону розподілу Вейбула. Виконаний аналіз показав, що $i$ в автотрансформаторах напругою 330 кB, і в трансформаторах напругою 110 кB має місце зміщення між математичними очікуваннями щиільності розподілу показників масел придатного до експлуатації. Наявність даного зміщення дозволяє використовувати отриманні з урахуванням умов експлуатаџї значення параметрів законів розподілу для оцінки відпраџьованого ресурсу масел, а також для прогнозування та планування термінів обслуговування та ремонту обладнання. Бібл. 38, табл. 7, рис. 5.

Ключові слова: трансформаторне масло, показники масел, тривалість експлуатації, статистичний аналіз, закони розподілу, критерії згоди, розподіл Вейбула, функції щільності розподілу.

В статье приведень результать анализа законов распределения показателей трансформаторных масел в трансформаторах 110 и 330 кВ. Установлено, что распределение показателей как для масла годного, так и негодного к эксплуатации, вне зависимости от класса напряжения трансформаторов подчиняются закону распределения Вейбулла. Выполненный анализ показал, что и в автотрансформаторах напряжением $330 \mathrm{\kappa B}$, и в трансформаторах напряжением $110 \kappa B$ имеет место смещение между математическими ожиданиями плотностей распределения показателей масел годного к эксплуатации. Наличие данного смещения позволяет использовать полученные с учетом условий эксплуатации, значения параметров законов распределения для оценки отработанного ресурса масел, а также для прогнозирования и планирования сроков обслуживания и ремонта оборудования. Библ. 38, табл. 7, рис. 5.

Ключевые слова: трансформаторное масло, показатели масел, длительность эксплуатации, статистический анализ, законы распределения, критерии согласия, распределение Вейбулла, функции плотности распределения.

Introduction. Accidental damage of high-voltage power transformers is accompanied by significant economic damage and in some cases can have serious consequences [1]. Given the significant ageing of highvoltage power transformers in Ukraine and in most foreign countries, as well as the extremely low rate of equipment replacement that has reached the end of its life, ensuring the operational reliability of transformers is an important scientific and practical task. One of the elements of insulation of high-voltage power transformers is petroleum insulating oils. As shown in $[2,3]$, the condition of transformer oils has a significant role in ensuring the operational reliability of transformers. Oil oxidation products have a negative effect not only on the electrical strength of the liquid insulation, but also contribute to a reduction in the mechanical strength of the cellulose insulation, which leads to a reduction in the transformer service life. In this regard, the improvement of methods for assessing the condition of transformer oils is an urgent task. The solution of this problem will increase the operational reliability of high-voltage power transformers and extend their service life.

Publication analysis and research problem statement. At present, a great deal of research is devoted

(C) O. Shutenko, S. Ponomarenko 
to the improvement of methods for diagnosing the condition of transformer oils. Improvement is carried out in two main directions - the use of new methods of measurement (for example, [4-8]) and improvement of decision-making methods. For example, in [9-12] neural networks of different configurations are proposed to diagnose the condition and predict the values of transformer oil indicators. In [13, 14], oil condition assessment was performed using Markov networks. In $[15,16]$ fuzzy logic was applied, and in [17-19] regression models were used. Considering that under real operating conditions the condition of oils is evaluated by comparing the measured values of indicators with maximum permissible values (MPV), which are regulated by international or national standards [20, 21], in [22-24] a correction of MPV indicators of transformer oils was performed. However, in these studies, integral distribution functions were used to correct MPV, and the laws themselves were not analysed. At the same time, as shown in $[25,26]$, the use of statistical decision methods, taking into account the distribution laws of diagnostic indicators to correct MPV allows to significantly reduce the risks compared to the method of integral functions. In addition, the parameters of distribution laws are widely used in the development of models for predicting the residual life of equipment, e.g. [27]. Meanwhile, the analysis showed that the analysis of distribution laws of transformer oil indicators has not found sufficient coverage in the literature. An exception is the research carried out in [28] according to which oil indicators such as organic acid content (OAC), breakdown voltage (BDV), interfacial tension, oil resistivity and water content can be described by a Weibull distribution. However, the differences in the values of the oil distribution parameters obtained before filling and aged oils are insignificant, which requires further verification. Therefore, this paper presents the results of the analysis of distribution laws for the whole set of transformer oil parameters in the tanks of $110 \mathrm{kV}$ transformers and $330 \mathrm{kV}$ autotransformers.

Statistical processing of periodic test results. The results of periodic transformer oil BDV monitoring for the 231 transformers of $110 \mathrm{kV}$ and 49 autotransformers of $330 \mathrm{kV}$ were used as input data. The total volume of the analysed sample amounted to 21062 values, of which 17408 were obtained for $110 \mathrm{kV}$ transformers, while 3654 were obtained for $330 \mathrm{kV}$ autotransformers. The list of transformer oil indicators and the volume of sample values for each indicator are shown in Table 1.

The sample presented in Table 1 is heterogeneous both in terms of the number of transformers and of the total number of indicator values. This heterogeneity is due to several factors. For example, for such indicator as the transformer oil colour, the current Ukrainian standard [21] regulates the maximum permissible values only for new oil, and for in-service control such values are not regulated, but must be taken into account when assessing the condition of oils. This circumstance is one of the reasons that the oil colour is monitored not in all power companies in Ukraine. Insignificant amounts of sampling values for such indicators as water-soluble acids, mechanical impurities and water content are because the current standards allowed the use of several methods to determine the values of these indicators: indicative (absent or present) and quantitative (determined quantitative content of these indicators in $\mathrm{mg} \mathrm{KOH} / \mathrm{g}$ or $\mathrm{g} / \mathrm{t}$ ). Since the diagnosis «absent» using indicator methods is not equivalent to zero, only the results of quantitative methods were used for further analysis.

Table 1

List of indicators for transformer oils and volume of sample values for each indicator

\begin{tabular}{|c|c|c|c|}
\hline \multirow[b]{2}{*}{ No. } & \multirow[b]{2}{*}{ Oil quality indicator } & \multicolumn{2}{|c|}{ Volume of sample values } \\
\hline & & $\begin{array}{l}\text { Number of } \\
\text { transformers }\end{array}$ & $\begin{array}{c}\text { Number of } \\
\text { values }\end{array}$ \\
\hline \multicolumn{4}{|c|}{$110 \mathrm{kV}$ transformers } \\
\hline 1 & Flash point & 230 & 3746 \\
\hline 2 & Acid number & 231 & 3741 \\
\hline 3 & BDV & 231 & 3723 \\
\hline 4 & $\operatorname{tg} \delta$ at $20^{\circ} \mathrm{C}$ & 31 & 268 \\
\hline 5 & $\operatorname{tg} \delta$ at $70^{\circ} \mathrm{C}$ & 50 & 426 \\
\hline 6 & $\operatorname{tg} \delta$ at $90^{\circ} \mathrm{C}$ & 60 & 570 \\
\hline 7 & Oil colour & 121 & 2108 \\
\hline 8 & Water-soluble acid content & 46 & 1191 \\
\hline 9 & Water content & 73 & 1635 \\
\hline \multicolumn{4}{|c|}{$330 \mathrm{kV}$ autotransformers } \\
\hline 1 & Flash point & 49 & 887 \\
\hline 2 & Acid number & 48 & 850 \\
\hline 3 & BDV & 49 & 852 \\
\hline 4 & $\operatorname{tg} \delta$ at $90^{\circ} \mathrm{C}$ & 45 & 543 \\
\hline 5 & Water content & 30 & 400 \\
\hline 6 & Contamination content & 20 & 122 \\
\hline
\end{tabular}

Since the test results were obtained in different laboratories and the transformers analysed have different service lives, are operated with different loads and are filled with different oil types, it is obvious that the oil ageing intensity in the analysed transformers varies considerably. In other words, the raw data is statistically heterogeneous. As an example, Fig. 1, $a$ shows the dielectric dissipation factor of transformer oils measured at $90{ }^{\circ} \mathrm{C}$ for $330 \mathrm{kV}$ autotransformers. The heterogeneity of the raw data in the figure is due to both differences in the quality of the oil filled (relatively high values of $\operatorname{tg} \delta$ measured at $90{ }^{\circ} \mathrm{C}$ at the start of operation) and differences in operating conditions (low values of this indicator were obtained with a fairly long service life). In addition, there are errors in the test results. The heterogeneity of the raw data leads to the empirical distribution histogram distortion (Fig. 1,b), which does not allow an evaluation of the distribution laws for transformer oils.

In this regard, there is a task of forming homogeneous arrays of transformer oil indicators. At the first stage, from the initial data set were selected values of indicators that go beyond the area of MPV, regulated by the current normative document in Ukraine [21]. Using basic terms from the theory of technical diagnostics [29], denote the data set, consisting of the results of tests for an oil usable by the values of indicators as $D_{1}$. Data set consisting of test results for unusable oil as $D_{2}$. 
Two approaches are used to generate homogeneous indicator arrays. The first approach is based on the use of mathematical models of variance analysis and, as shown in $[30,31]$, allows obtaining sufficiently correct integral distribution functions of diagnostic attributes. A significant limitation of this approach is the limited information about the operating modes of transformers, the specifics of their design, the materials used. This may cause erroneous conclusions. The second approach is based on the use of statistical hypothesis tests and, as shown in [32], allows estimating the distribution laws of diagnostic attributes. The disadvantage of this approach is the difficulty in establishing the relationship between the parameters of the distribution laws of diagnostic indicators and the factors affecting the ageing intensity.
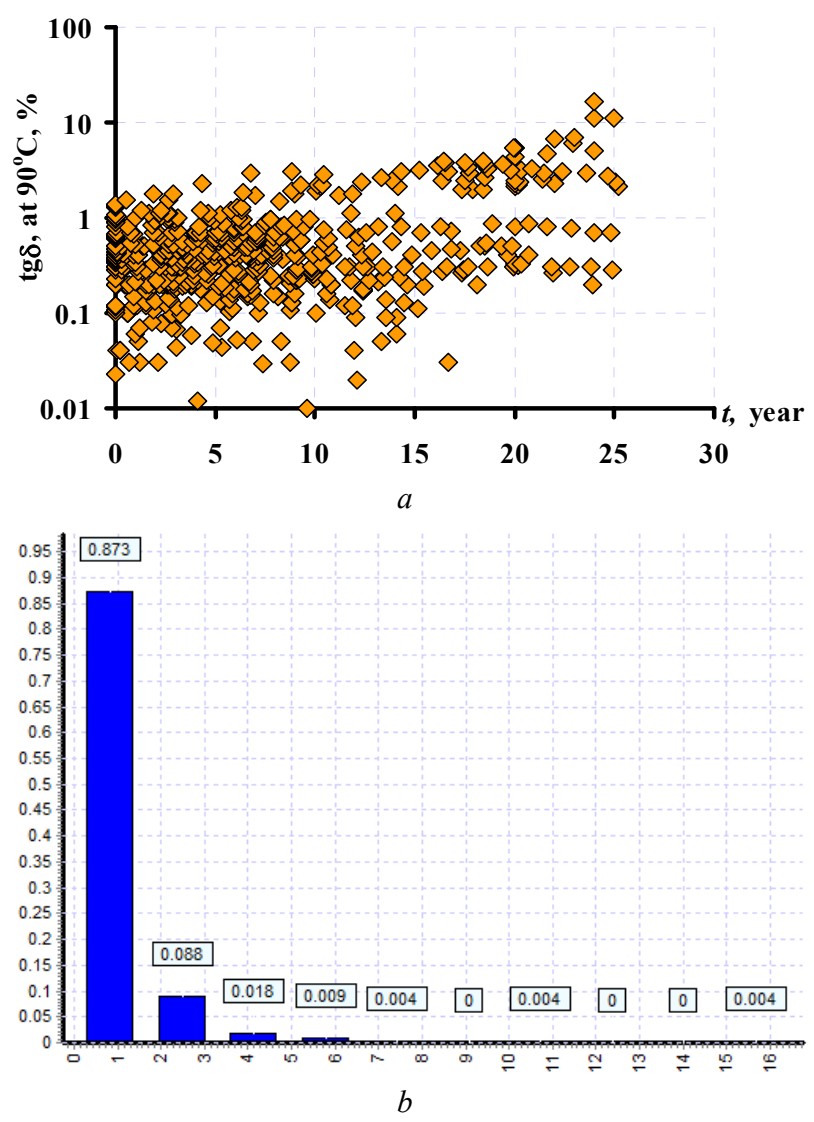

Fig. 1. Dependence of the dielectric dissipation factor of transformer oils measured at $90{ }^{\circ} \mathrm{C}$ in $330 \mathrm{kV}$ autotransformers

on the operating time for the original data set $(a)$ and the corresponding empirical distribution histogram $(b)$

It is known [33] that the main factors influencing the intensity of oil oxidation are temperature, air oxygen content, duration of oxidation and the influence of some structural materials (copper, varnished insulating fabric, not oil resistant rubber, etc.). Considering that the date of oil filling is known for each of the transformers under consideration, the duration of oil ageing is not very difficult to account for. However, during long-term operation, the oil can be dried, regenerated, refilled or replaced both oil and silica gel, which leads to a distortion of the performance dependence on the operating time. In order to eliminate this problem, the results of the periodic tests for such transformers were divided into several groups (for example, from the time of oil filling and to the regeneration date and from the regeneration date to the date of the last test) in a preliminary statistical processing step. The insulation temperature of power transformers $[34,35]$ depends on both the value of load currents and the ambient temperature, as well as on the transformer cooling system. The transformers under consideration are operated in the same climatic zone with similar values of average daily temperatures, and have an identical cooling system (with oil natural and air forced for $110 \mathrm{kV}$ transformers, and with oil forced and air forced for $330 \mathrm{kV}$ autotransformers). Therefore, it is logical to assume that differences in oil oxidation intensity caused by different operating temperature values, which are due to differences in load currents [36]. Under conditions where transformer load information is partially available, a statistical hypothesis test approach was used to generate homogeneous arrays of indicators.

Arrays with homogeneous periodic test results were generated by using three statistical criteria [32]:

1. Wilcoxon rank-sum test $(W)$ is used to test the statistical hypothesis of similarity of distribution laws of two independent samples:

$$
W=\sum_{i=1}^{n} s\left(r_{i}\right),
$$

where $r_{i}$ are the ranks of the diagnostic indicators in the overall variation series; $s\left(r_{i}\right)$ is one of the possible $N$ ! permutations of rank $r_{i}$.

2. Z-criterion $(Z)$ is used to test the statistical hypothesis of equality of mathematical expectations of two independent samples:

$$
Z_{\mathrm{obs}}=\frac{\bar{x}_{1}-\bar{x}_{2}}{\sqrt{\frac{\delta_{1}^{2}}{n}+\frac{\delta_{2}^{2}}{m}}}
$$

where $\bar{x}_{1}$ and $\bar{x}_{2}$ are the selective mean of the diagnostic indicator calculated from the first and second transformer test results respectively; $\delta_{1}^{2}$ and $\delta_{2}^{2}$ are the selective variance of the diagnostic indicator calculated from the first and second transformer test results respectively; $n$ and $m$ are the number of observations of the diagnostic indicator for the first and second transformer respectively.

3. Fisher-Snedecor $F$ distribution $(F)$ is used to test the statistical hypothesis of dispersions equality of two independent samples:

$$
F_{\mathrm{obs}}=\frac{\delta_{\max }^{2}}{\delta_{\min }^{2}},
$$

where $\delta_{\max }^{2}$ and $\delta_{\min }^{2}$ are the values of the maximum and minimum sampling variance.

Two independent samples were considered homogeneous if the following statistical hypotheses were not rejected by the test results at the given significance level $\alpha=0.05$ :

1. about similarity of distribution laws of two independent samples $\left(W_{1}>W_{n 1, n 2,0,025}, W_{2}<W_{n 1, n 2,0,975}\right)$; 
2. about equality of mathematical expectations of two independent samples $\left(Z_{\mathrm{obs}}<Z_{\text {crit }, 0,95}\right)$;

3. about dispersions equality of two independent samples $\left(F_{\text {obs }}<F_{(n 1-1),(n 2-1), 0,95}\right)$.

The above algorithm for statistical processing of test results was implemented as the author's software «Odnorodn» [37], which significantly reduces the time required for statistical processing of raw data. Using this software in relation to the analysed data sample allowed forming several arrays of indicators with close values of sample means, sample variance and similar distribution laws. The volume of sample values $(N)$, values of sample mean $\left(M_{x}\right)$, sample variance $\left(D_{x}\right)$ as well as skewness $\left(j_{s}\right)$ and kurtosis $\left(j_{k}\right)$ coefficients for the original data sets $\left(D_{10}\right)$ and those obtained from statistical processing $\left(D_{11}-D_{1 n}\right)$ of usable oil indicators for $110 \mathrm{kV}$ transformers are given in Table 2 and for $330 \mathrm{kV}$ autotransformers in Table 3.

Comparison of statistical characteristics of initial arrays of oil indicators with similar characteristics of indicators from the arrays obtained after statistical processing showed that using statistical processing procedure allowed significantly reducing the $D_{x}$, as well as the $j_{s}$ and $j_{k}$ for almost all indicators. Analysis of statistical characteristics of the arrays of indicators obtained through statistical processing shows that the values of mathematical expectation of the usable oil indicators differ significantly. This indicates both different quality of transformer oil and different oil ageing intensity, that is, differences in transformer operation modes. As can be seen from Tables, negative skewness coefficients (the «long part» of the distribution curve is to the left of the mathematical expectation) are obtained mainly for the indicators which decrease in value during ageing (flash point and BDV). For the oil indicators which increase with oil ageing (organic and water-soluble acid content, $\operatorname{tg} \delta$, oil colour, water content, contamination content), the majority of the obtained arrays show positive skewness values («long part» of the distribution curve is to the right of the mathematical expectation).

The presence of a negative skewness for some of the indicator data sets indicates a deterioration in the condition of the transformer oil; there are more «high values» of the indicators than low ones. As can be seen from the tables, there is a positive kurtosis coefficient for all indicator arrays, indicating that the distribution curve has a higher and «sharper» peak than the curve of the normal law. The obtained empirical values of skewness and kurtosis coefficients indirectly indicate that the distribution of usable oil indicators may differ from the normal law.

The analysis showed that the homogeneous arrays were formed by testing transformers with close operating times and similar values of load factors. This made it possible to establish an unambiguous relationship between the operating conditions of the transformers and the values of the distribution law parameters.

The processing of the results of periodic tests on oils which have exceeded the MPV (unusable oil) was carried out in the following sequence. First, data sets were
Table 2

Statistical characteristics of homogeneous arrays of $110 \mathrm{kV}$ transformer usable oil

\begin{tabular}{|c|c|c|c|c|c|}
\hline Array & $N$ & $M_{x}$ & $D_{x}$ & $j_{s}$ & $j_{k}$ \\
\hline \multicolumn{6}{|c|}{ Flash point } \\
\hline $\mathrm{D}_{10}$ & 3746 & 143.579418 & 13.06904 & 0.809 & 4.281 \\
\hline $\mathrm{D}_{11}$ & 284 & 140.059859 & 2.866135 & -0.346 & 3.693 \\
\hline $\mathrm{D}_{12}$ & 364 & 142.931319 & 2.030997 & -0.385 & 4.521 \\
\hline $\mathrm{D}_{13}$ & 185 & 144.535135 & 3.600117 & -0.144 & 2.361 \\
\hline $\mathrm{D}_{14}$ & 188 & 146.930851 & 15.968623 & -0.088 & 3.404 \\
\hline $\mathrm{D}_{15}$ & 280 & 149.089286 & 9.988457 & -0.172 & 3.308 \\
\hline \multicolumn{6}{|c|}{ Organic acid content } \\
\hline $\mathrm{D}_{10}$ & 3339 & 0.034848 & 0.000592 & 0.817 & 2.685 \\
\hline $\mathrm{D}_{11}$ & 218 & 0.015311 & 0.000087 & 0.587 & 2.472 \\
\hline$D_{12}$ & 198 & 0.027884 & 0.00007 & 0.711 & 3.303 \\
\hline $\mathrm{D}_{13}$ & 250 & 0.045944 & 0.000395 & 0.175 & 2.262 \\
\hline $\mathrm{D}_{14}$ & 129 & 0.046434 & 0.000192 & -0.175 & 2.907 \\
\hline$D_{15}$ & 156 & 0.051679 & 0.000446 & 0.224 & 2.462 \\
\hline $\mathrm{D}_{16}$ & 361 & 0.045917 & 0.000500 & 0.807 & 3.988 \\
\hline $\mathrm{D}_{17}$ & 333 & 0.064655 & 0.001557 & 0.690 & 2.978 \\
\hline \multicolumn{6}{|c|}{ BDV } \\
\hline $\mathrm{D}_{10}$ & 3435 & 58.262667 & 116.058219 & 0.109 & 2.627 \\
\hline $\mathrm{D}_{11}$ & 135 & 49.038519 & 44.673183 & 0.0748 & 2.423 \\
\hline$D_{12}$ & 609 & 60.654351 & 115.838869 & -0.249 & 2.468 \\
\hline $\mathrm{D}_{13}$ & 360 & 68.110833 & 123.619522 & -0.350 & 2.620 \\
\hline $\mathrm{D}_{14}$ & 286 & 69.421678 & 109.698341 & -0.524 & 2.902 \\
\hline$D_{15}$ & 204 & 71.066176 & 124.016356 & -0.657 & 3.038 \\
\hline \multicolumn{6}{|c|}{$\operatorname{tg} \delta$ at $20^{\circ} \mathrm{C}$} \\
\hline $\mathrm{D}_{10}$ & 268 & 0.182246 & 0.067281 & 7.962 & 83.730 \\
\hline $\mathrm{D}_{11}$ & 109 & 0.141835 & 0.008986 & 0.793 & 3.075 \\
\hline $\mathrm{D}_{12}$ & 141 & 0.188596 & 0.014915 & 0.959 & 3.713 \\
\hline \multicolumn{6}{|c|}{$\operatorname{tg} \delta$ at $70^{\circ} \mathrm{C}$} \\
\hline $\mathrm{D}_{10}$ & 426 & 0.917268 & 2.170500 & 7.513 & 82.291 \\
\hline $\mathrm{D}_{11}$ & 112 & 0.290446 & 0.038860 & 0.951 & 3.284 \\
\hline $\mathrm{D}_{12}$ & 161 & 0.593634 & 0.162197 & 1.051 & 3.892 \\
\hline$D_{13}$ & 140 & 0.850321 & 0.306149 & 0.991 & 4.229 \\
\hline \multicolumn{6}{|c|}{$\operatorname{tg} \delta$ at $90^{\circ} \mathrm{C}$} \\
\hline $\mathrm{D}_{10}$ & 570 & 1.297158 & 12.095330 & 13.686 & 219.667 \\
\hline$D_{11}$ & 148 & 0.485811 & 0.126923 & 1.189 & 4.664 \\
\hline$D_{12}$ & 159 & 0.548679 & 0.133394 & 1.071 & 4.527 \\
\hline$D_{13}$ & 152 & 1.504605 & 1.133087 & 0.793 & 3.119 \\
\hline$D_{14}$ & 99 & 1.863737 & 1.848464 & 0.893 & 3.297 \\
\hline \multicolumn{6}{|c|}{ Oil colour } \\
\hline $\mathrm{D}_{10}$ & 2108 & 2.574953 & 1.769050 & 0.822 & 2.870 \\
\hline $\mathrm{D}_{11}$ & 650 & 1.896923 & 0.597837 & 0.391 & 2.606 \\
\hline $\mathrm{D}_{12}$ & 484 & 3.026860 & 3.096386 & 0.587 & 2.354 \\
\hline $\mathrm{D}_{13}$ & 657 & 3.060122 & 1.917618 & 0.128 & 2.131 \\
\hline \multicolumn{6}{|c|}{ Water-soluble acid content } \\
\hline $\mathrm{D}_{10}$ & 1191 & 0.006106 & 0.000281 & 11.835 & 257.889 \\
\hline $\mathrm{D}_{11}$ & 108 & 0.004359 & 0.000005 & 1.452 & 6.673 \\
\hline$D_{12}$ & 231 & 0.005529 & 0.000006 & 0.025 & 2.611 \\
\hline $\mathrm{D}_{13}$ & 92 & 0.006315 & 0.000009 & 0.194 & 2.655 \\
\hline $\mathrm{D}_{14}$ & 116 & 0.006892 & 0.000008 & 0.182 & 2.301 \\
\hline$D_{15}$ & 91 & 0.007679 & 0.000007 & -0.120 & 2.684 \\
\hline \multicolumn{6}{|c|}{ Water content } \\
\hline $\mathrm{D}_{10}$ & 1635 & 14.381787 & 116.663877 & 2.723 & 10.436 \\
\hline $\mathrm{D}_{11}$ & 284 & 7.963 & 13.993306 & 0.511 & 2.773 \\
\hline $\mathrm{D}_{12}$ & 546 & 9.2768 & 20.054587 & 0.469 & 2.375 \\
\hline$D_{13}$ & 520 & 10.748 & 16.643352 & 0.028 & 2.363 \\
\hline
\end{tabular}


generated for each of the indicators for which a deterioration of the MPV values was detected. To ensure «equality» between the different transformers, a strictly fixed number of observations was selected for each of the indicators for each transformer.

Table 3

Statistical characteristics of homogeneous arrays of $330 \mathrm{kV}$ autotransformer usable oil

\begin{tabular}{|c|c|c|c|c|c|}
\hline Array & $N$ & $M_{x}$ & $D_{x}$ & $j_{s}$ & $j_{k}$ \\
\hline \multicolumn{6}{|c|}{ Flash point } \\
\hline $\mathrm{D}_{10}$ & 856 & 141.848131 & 10.217590 & 0.471 & 3.210 \\
\hline$D_{11}$ & 174 & 148.063218 & 4.358072 & -0.481 & 3.198 \\
\hline $\mathrm{D}_{12}$ & 131 & 146.122137 & 2.534701 & -0.495 & 2.794 \\
\hline $\mathrm{D}_{13}$ & 241 & 144.792531 & 1.873969 & -0.282 & 4.092 \\
\hline $\mathrm{D}_{14}$ & 100 & 139.360000 & 2.590400 & -0.408 & 2.882 \\
\hline \multicolumn{6}{|c|}{ Organic acid content } \\
\hline $\mathrm{D}_{10}$ & 850 & 0.015665 & 0.000662 & 15.882 & 356.965 \\
\hline $\mathrm{D}_{11}$ & 180 & 0.007010 & 0.000007 & 0.253 & 3.007 \\
\hline $\mathrm{D}_{12}$ & 99 & 0.007542 & 0.000009 & 0.090 & 2.585 \\
\hline $\mathrm{D}_{13}$ & 110 & 0.008343 & 0.000010 & 0.104 & 2.497 \\
\hline $\mathrm{D}_{14}$ & 114 & 0.008546 & 0.000010 & -0.015 & 2.636 \\
\hline $\mathrm{D}_{15}$ & 206 & 0.019877 & 0.000140 & 0.794 & 3.373 \\
\hline \multicolumn{6}{|c|}{ BDV } \\
\hline $\mathrm{D}_{10}$ & 852 & 68.995188 & 84.716867 & -1.481 & 10.952 \\
\hline$D_{11}$ & 210 & 74.162857 & 60.864239 & -0.193 & 3.252 \\
\hline $\mathrm{D}_{12}$ & 240 & 68.347500 & 53.851160 & -0.267 & 3.169 \\
\hline $\mathrm{D}_{13}$ & 149 & 66.809396 & 68.887612 & -0.286 & 2.630 \\
\hline $\mathrm{D}_{14}$ & 130 & 65.853077 & 93.476029 & 0.0193 & 2.441 \\
\hline \multicolumn{6}{|c|}{$\operatorname{tg} \delta$ at $90^{\circ} \mathrm{C}$} \\
\hline $\mathrm{D}_{10}$ & 543 & 0.836640 & 2.408043 & 6.572 & 62.575 \\
\hline $\mathrm{D}_{11}$ & 162 & 0.212093 & 0.018112 & 0.986 & 3.825 \\
\hline $\mathrm{D}_{12}$ & 67 & 0.701701 & 0.124185 & 1.465 & 5.622 \\
\hline $\mathrm{D}_{13}$ & 133 & 0.833985 & 0.432406 & 1.486 & 4.726 \\
\hline $\mathrm{D}_{14}$ & 138 & 1.691609 & 0.984824 & 0.473 & 2.499 \\
\hline \multicolumn{6}{|c|}{ Contamination content } \\
\hline $\mathrm{D}_{10}$ & 122 & 7.893852 & 32.249573 & 2.624 & 11.631 \\
\hline$D_{11}$ & 65 & 7.239231 & 9.591576 & 0.835 & 4.23 \\
\hline $\mathrm{D}_{12}$ & 53 & 10.146226 & 59.996212 & 1.549 & 5.378 \\
\hline \multicolumn{6}{|c|}{ Water content } \\
\hline $\mathrm{D}_{10}$ & 400 & 10.123280 & 30.923324 & 1.702 & 11.803 \\
\hline $\mathrm{D}_{11}$ & 95 & 4.725653 & 9.111732 & 1.987 & 8.985 \\
\hline $\mathrm{D}_{12}$ & 155 & 9.543226 & 17.576746 & 0.227 & 2.332 \\
\hline
\end{tabular}

Similar to [32], an approach based on the extraction of gross omissions from a number of similar measurements was used to further process of the unusable oil indicators values. For this purpose, the Irwin criterion was used, which can be applied when the distribution law of a random variable is unknown or differs from the normal distribution. The values of the oil indicators were sorted in descending order for this purpose, after which the "suspicious» values of the BDV at the boundaries of the variation series were evaluated. The value of the Irwin criterion was defined as:

$$
\eta_{\text {calc }}=\frac{\left(x_{k}-x_{k \text { prev }}\right)}{S},
$$

where $x_{k}$ is the suspicious value; $x_{k}$ prev is the previous value in the variation series.

The calculated value of the Irwin criterion was compared with the table value $\eta_{\text {table. If }} \eta_{\text {calc }}>\eta_{\text {table, }}$, then the considered value was rejected and the next value was checked. The test was continued until $\eta_{\text {calc }}<\eta_{\text {table }}$

By analogy with Tables 2 and 3, Table 4 shows the same attributes for the data sets obtained during statistical processing of unusable oil values for $110 \mathrm{kV}$ transformers. In the table, array $\mathrm{D}_{21}$ is based on the results of transformers with less than 20 years of service life, and array $\mathrm{D}_{22}$ is based on the results of transformers with more than 20 years of service life.

Table 4

Statistical characteristics of homogeneous arrays of indicators of unusable oil

\begin{tabular}{|c|c|c|c|c|c|}
\hline Array & $N$ & $M_{x}$ & $D_{x}$ & $j_{s}$ & $j_{k}$ \\
\hline \multicolumn{7}{|c|}{ Org kV transformers acid content } \\
\hline \multicolumn{7}{|c|}{ BDV } \\
\hline $\mathrm{D}_{21}$ & 303 & 0.177673 & 0.001155 & -0.176 & 2.421 \\
\hline $\mathrm{D}_{22}$ & 141 & 0.283191 & 0.000225 & -0.092 & 2.402 \\
\hline \multicolumn{7}{|c|}{ Water-soluble acid content } \\
\hline $\mathrm{D}_{2}$ & 275 & 27.647 & 19.814 & -0.653 & 3.083 \\
\hline \multicolumn{7}{|c|}{ Water content } \\
\hline $\mathrm{D}_{2}$ & 192 & 0.035904 & 0.000154 & 0.550 & 3.040 \\
\hline \multicolumn{7}{|c|}{ Organic acid content } \\
\hline $\mathrm{D}_{2}$ & 164 & 36.333659 & 100.10887 & 0.505 & 3.097 \\
\hline \multicolumn{7}{|c|}{ BDV } \\
\hline \multicolumn{7}{|c|}{ Water content } \\
\hline $\mathrm{D}_{2}$ & 136 & 0.137456 & 0.000273 & -0.0113 & 3.200 \\
\hline \multicolumn{7}{|c|}{} \\
\hline $\mathrm{D}_{2}$ & 123 & 41.550894 & 4.880138 & -0.666 & 2.875 \\
\hline \multicolumn{7}{|c|}{} \\
\hline $\mathrm{D}_{2}$ & 132 & 29.287879 & 22.728261 & -0.0120 & 2.237 \\
\hline
\end{tabular}

By comparing the statistical characteristics for the respective indicators for usable and unusable oil, it can be seen that the main difference between them is the values of the sample means.

Analysis of the distribution laws for transformer oils. To test the hypothesis that the theoretical distribution law corresponds to empirical data, the software «ZR» developed at the Electric Power Transmission Department of National Technical University «Kharkiv Polytechnic Institute» was used [37]. This software allows splitting the range of variation of a random variable into intervals, for which the Sturges' rule is used by default:

$$
L=1+3,322 \cdot \lg N \text {, }
$$

where $N$ is the volume of sample values.

If necessary, the user can set the required number of intervals himself. A histogram of the empirical distribution is then drawn. The parameters for the normal, beta, exponential, extremal, gamma, Laplace, logistic, logarithmic normal, Rayleigh, Weibull and Pareto distribution laws are then estimated from the sample values. For each of the 11 distribution laws, the theoretical distribution law is checked for consistency with the empirical data, using two statistical criteria [38]: 
1) Pearson's chi-squared test $\left(\chi^{2}\right)$ :

$$
\chi^{2}=\sum_{i=1}^{k} \frac{\left(n_{i}-n_{i}^{\prime}\right)^{2}}{n_{i}^{\prime}}
$$

where $n_{i}$ are values of empirical frequencies; $n_{i}^{\prime}$ are values of theoretical frequencies; $k$ is the number of intervals.

To test the main hypothesis, the sample value of criterion $\chi^{2}$ is calculated and the critical point of criterion $\chi^{2}$ distribution, the given significance level $\alpha$ and the number of degrees of freedom $f$ are determined by the critical point $\chi_{\text {crit }}^{2}(\alpha ; f)$. The number of degrees of freedom $f$ is defined as $f=k-1-r$, where $k$ is the number of sample groups (partial intervals); $r$ is the number of estimated distribution parameters that are estimated from the sample data.

If the calculated value of $\chi^{2}$ criterion is less than the critical value, the main hypothesis - the general population is distributed according to the given law - is not rejected and vice versa.

2) Kolmogorov-Smirnov test:

$$
D_{n}=\sup _{x}\left|F_{n}(x)-F(x)\right|,
$$

where $F_{n}(x)$ is the empirical distribution function; $F(x)$ is the theoretical distribution function.

The main hypothesis is rejected if $\sqrt{n} \cdot D_{n}$ exceeds the distribution quantile $K \alpha$ of the given significance level $\alpha$, and is not rejected otherwise [38].

Analysis by the software showed that both usable and unusable oil values could be described by a Weibull distribution, with a distribution density as follows:

$$
p(x ; \alpha ; \beta)=\frac{\beta}{\alpha^{\beta}} \cdot x^{\beta-1} \cdot e^{-\left(\frac{x}{\alpha}\right)^{\beta}},
$$

where $\alpha$ and $\beta$ are distribution law parameters, interpreted as scale and shape parameter, respectively.

The value of the $\alpha$ and $\beta$ parameters was defined as:

$$
\left.\begin{array}{c}
\alpha=\frac{M(x)}{1-0.427 \cdot(\beta-1) \cdot \beta^{-1.9}} ; \\
0.465 \cdot \frac{\left[\frac{1}{N} \cdot \sum_{i=1}^{N}\left(x_{i}-M(x)\right)^{2}\right]^{\frac{1}{2}}}{M(x)} \cdot\left(\begin{array}{c}
M(x) \\
\left.+1.282 \cdot \frac{1}{N} \cdot \sum_{i=1}^{N}\left(x_{i}-M(x)\right)^{2}\right]^{\frac{1}{2}}
\end{array}\right), 0.7
\end{array}\right),
$$

where $N$ is the volume of sample values; $M_{x}$ is the sample mean; $x_{i}$ is the indicator value.

However, during the analysis, for some of the arrays the main hypothesis was not rejected for several distribution laws. Thus, for distributions with positive skewness, in addition to the Weibull distribution, the empirical data were fit to the log-normal, gamma and Rayleigh distribution laws.

As an example, Fig. 2 shows histograms of the empirical distribution and the theoretical density functions
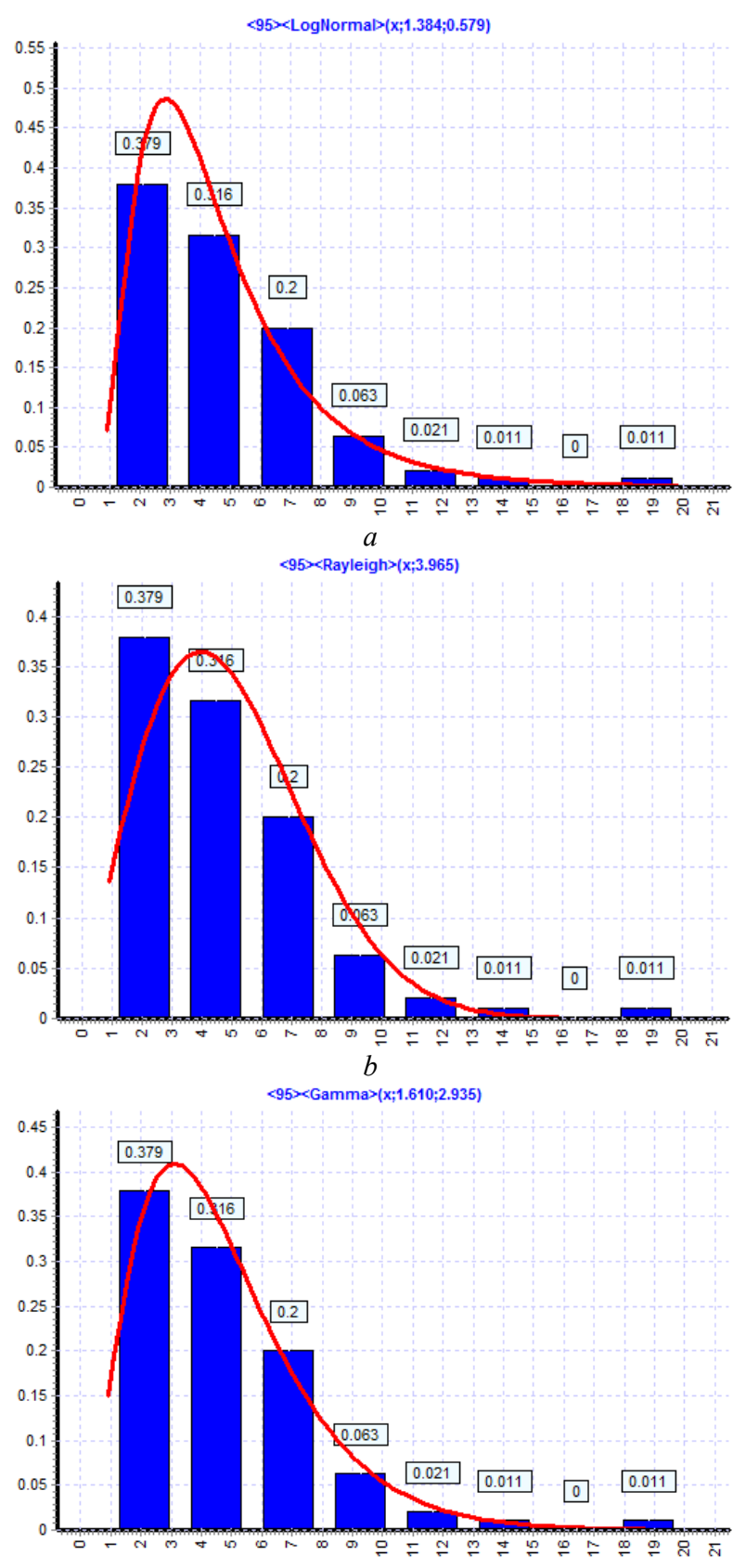

$c$

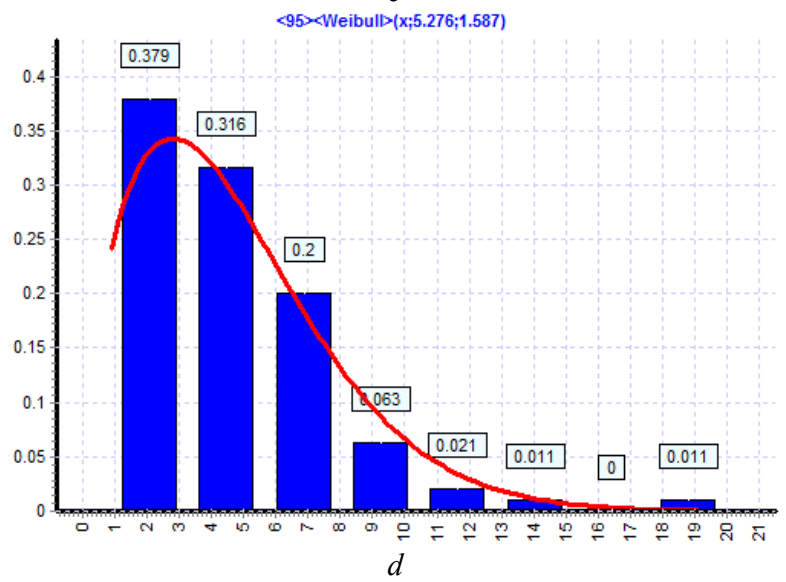

Fig. 2. Histograms of the empirical distribution and the theoretical density functions of some distributions for the water content of oil from the $D_{11}$ array of $330 \mathrm{kV}$ autotransformers: $a$ - log-normal distribution law; $b$ - Rayleigh distribution; $c$-gamma distribution; $d$ - Weibull distribution 
of these distributions for the water content of oil from the $D_{11}$ array of $330 \mathrm{kV}$ autotransformers.

For relatively symmetric distributions, in addition to the Weibull distribution, for some of the arrays the empirical data were found to fit the normal and logistic laws. However, for many arrays with negative skewness, the only distribution law corresponding to the empirical data was a Weibull distribution law.

The values of the Weibull distribution law parameters as well as the calculated and critical values of the Pearson and Kolmogorov-Smirnov tests for the indicators of usable oil in $110 \mathrm{kV}$ transformers are given in Table 5 and for $330 \mathrm{kV}$ autotransformers are given in Table 6.

The same, but for the unusable oil indicators are given in Table 7 . For the tables below, the $\lambda_{\text {crit }}$ value of the Kolmogorov-Smirnov test is 1.36 .

As can be seen from Tables 6, 7, the calculated values of the goodness of fit criteria for all transformer oil indicators without exception do not exceed the critical values at significance level $\alpha=0.05$ and the corresponding value of degrees of freedom. This does not allow rejecting the hypothesis about the acceptability of the distribution of empirical values of transformer oils to the Weibull distribution.

Results analysis. By analogy with [32], the analysis of the mutual arrangement of theoretical densities of distribution of the indicators of usable and unusable transformer oils in of 110 and $330 \mathrm{kV}$ transformers was carried out. As an example Figures 3-5 shows the densities of theoretical distributions for such indicators as the organic acid content (Fig. 3), water content (Fig. 4) and the BDV (Fig. 5) of the oil.

Analysing the mutual arrangement of the theoretical distribution densities of transformer oil indicators, several important conclusions can be drawn:

1. For the usable transformer oil for both $110 \mathrm{kV}$ transformers and $330 \mathrm{kV}$ autotransformers, there is a shift in the mathematical expectations of the distributions density for different arrays of the same indicator. This indicates a different oil ageing degree, which is caused by different oil service life, different operating temperatures of transformers as well as by the influence of structural materials.

2. Analysis of the distribution densities of usable oil for $110 \mathrm{kV}$ transformers and $330 \mathrm{kV}$ autotransformers shows that these distributions are also shifted in relation to each other. It is especially noticeable in the distribution densities of organic acids (Fig. 3) and water content of oils (Fig. 4). Thus, as can be seen from the figure the oxidation intensity of transformer oils in $330 \mathrm{kV}$ autotransformers is lower than in $110 \mathrm{kV}$ transformers, despite the fact that the analysed transformers were non-sealed.

3. The analysis shows that there is a significant shift between the mathematical expectations of the distributions of usable and unusable oil (Figures 3-5). This means that the residual life of the oils in the transformers analysed varies considerably.
Table 5

Values of the Weibull distribution law parameters as well as the calculated and critical values of the Pearson and Kolmogorov-

Smirnov tests for the indicators of usable oil in $110 \mathrm{kV}$ transformers

\begin{tabular}{|c|c|c|c|c|c|c|}
\hline \multirow{2}{*}{ 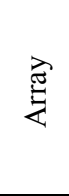 } & \multicolumn{2}{|c|}{$\begin{array}{l}\text { Distribution law } \\
\text { parameters }\end{array}$} & \multicolumn{3}{|c|}{$\begin{array}{l}\text { Value of Pearson's } \\
\text { chi-squared test }\end{array}$} & \multirow{2}{*}{$\begin{array}{c}\begin{array}{c}\text { Value of } \\
\text { Kolmogorov- } \\
\text { Smirnov test }\end{array} \\
\lambda_{\text {calc }}\end{array}$} \\
\hline & $\alpha$ & $\beta$ & $f$ & $\chi_{\text {calc }}^{2}$ & $\chi_{\text {crit }}^{2}$ & \\
\hline \multicolumn{7}{|c|}{ Flash point } \\
\hline $\mathrm{D}_{11}$ & 140.96 & 104.9 & 3 & 7.47 & 7.82 & 0.711 \\
\hline $\mathrm{D}_{12}$ & 143.71 & 127.5 & 4 & 8.59 & 9.49 & 1.194 \\
\hline $\mathrm{D}_{13}$ & 145.54 & 96.44 & 3 & 7.47 & 7.82 & 0.338 \\
\hline $\mathrm{D}_{14}$ & 148.91 & 46.2 & 4 & 8.26 & 9.49 & 0.694 \\
\hline $\mathrm{D}_{15}$ & 150.69 & 59.57 & 3 & 6.27 & 7.82 & 1.044 \\
\hline \multicolumn{7}{|c|}{ Organic acid content } \\
\hline $\mathrm{D}_{11}$ & 0.0172 & 1.682 & 6 & 10.47 & 12.6 & 0.711 \\
\hline $\mathrm{D}_{12}$ & 0.0308 & 3.706 & 5 & 21.26 & 11.1 & 1.001 \\
\hline $\mathrm{D}_{13}$ & 0.0518 & 2.454 & 6 & 8.54 & 12.6 & 0.654 \\
\hline $\mathrm{D}_{14}$ & 0.0514 & 3.702 & 4 & 7.92 & 9.49 & 0.674 \\
\hline $\mathrm{D}_{15}$ & 0.0581 & 2.611 & 5 & 10.68 & 11.1 & 0.800 \\
\hline $\mathrm{D}_{16}$ & 0.0519 & 2.154 & 4 & 6.074 & 9.49 & 0.545 \\
\hline $\mathrm{D}_{17}$ & 0.0725 & 1.679 & 6 & 10.96 & 12.6 & 0.760 \\
\hline \multicolumn{7}{|c|}{ BDV } \\
\hline $\mathrm{D}_{11}$ & 51.833 & 8.704 & 4 & 8.942 & 9.49 & 0.711 \\
\hline $\mathrm{D}_{12}$ & 64.963 & 6.596 & 7 & 12.03 & 14.1 & 0.607 \\
\hline $\mathrm{D}_{13}$ & 72.625 & 7.209 & 6 & 12.21 & 12.6 & 0.643 \\
\hline $\mathrm{D}_{14}$ & 73.726 & 7.84 & 5 & 6.419 & 11.1 & 0.606 \\
\hline $\mathrm{D}_{15}$ & 75.623 & 7.517 & 5 & 6.59 & 11.1 & 0.601 \\
\hline \multicolumn{7}{|c|}{$\operatorname{tg} \delta$ at $20^{\circ} \mathrm{C}$} \\
\hline $\mathrm{D}_{11}$ & 0.1576 & 1.515 & 4 & 9.439 & 9.49 & 1.017 \\
\hline $\mathrm{D}_{12}$ & 0.2103 & 1.569 & 4 & 9.095 & 9.49 & 0.639 \\
\hline \multicolumn{7}{|c|}{$\operatorname{tg} \delta$ at $70{ }^{\circ} \mathrm{C}$} \\
\hline $\mathrm{D}_{11}$ & 0.3221 & 1.491 & 4 & 5.079 & 9.49 & 0.697 \\
\hline $\mathrm{D}_{12}$ & 0.6585 & 1.496 & 4 & 6.465 & 9.49 & 0.673 \\
\hline $\mathrm{D}_{13}$ & 0.9478 & 1.562 & 4 & 1.865 & 9.49 & 0.311 \\
\hline \multicolumn{7}{|c|}{$\operatorname{tg} \delta$ at $90^{\circ} \mathrm{C}$} \\
\hline $\mathrm{D}_{11}$ & 0.5327 & 1.379 & 3 & 2.296 & 7.82 & 0.329 \\
\hline $\mathrm{D}_{12}$ & 0.6101 & 1.526 & 3 & 1.173 & 7.82 & 0.275 \\
\hline $\mathrm{D}_{13}$ & 1.6593 & 1.432 & 3 & 4.737 & 7.82 & 0.734 \\
\hline $\mathrm{D}_{14}$ & 2.0442 & 1.383 & 3 & 2.764 & 7.82 & 0.383 \\
\hline \multicolumn{7}{|c|}{ Oil colour } \\
\hline $\mathrm{D}_{11}$ & 2.1334 & 2.631 & 3 & 6.794 & 7.82 & 0.690 \\
\hline $\mathrm{D}_{12}$ & 3.4054 & 1.772 & 4 & 8.456 & 9.49 & 0.739 \\
\hline $\mathrm{D}_{13}$ & 3.453 & 2.339 & 3 & 6.523 & 7.82 & 0.656 \\
\hline \multicolumn{7}{|c|}{ Water-soluble acid content } \\
\hline $\mathrm{D}_{11}$ & 0.0049 & 1.986 & 2 & 2.765 & 5.99 & 0.449 \\
\hline $\mathrm{D}_{12}$ & 0.0062 & 2.365 & 6 & 6.383 & 12.6 & 0.446 \\
\hline $\mathrm{D}_{13}$ & 0.0071 & 2.207 & 4 & 1.468 & 9.49 & 0.288 \\
\hline $\mathrm{D}_{14}$ & 0.0078 & 2.554 & 4 & 3.736 & 9.49 & 0.378 \\
\hline $\mathrm{D}_{15}$ & 0.0086 & 3.112 & 3 & 2.277 & 7.82 & 0.344 \\
\hline \multicolumn{7}{|c|}{ Water content } \\
\hline $\mathrm{D}_{11}$ & 8.9923 & 2.239 & 5 & 2.137 & 11.1 & 0.279 \\
\hline $\mathrm{D}_{12}$ & 10.478 & 2.176 & 7 & 10.06 & 14.1 & 0.552 \\
\hline $\mathrm{D}_{13}$ & 12.05 & 2.849 & 7 & 8.763 & 14.1 & 0.385 \\
\hline
\end{tabular}


Table 6 Values of the Weibull distribution law parameters as well as the calculated and critical values of the Pearson and Kolmogorov-

Smirnov tests for the indicators of usable oil in $330 \mathrm{kV}$ autotransformers

\begin{tabular}{|c|c|c|c|c|c|c|}
\hline \multirow{2}{*}{$\underset{\overparen{E}}{\overparen{Z}}$} & \multicolumn{2}{|c|}{$\begin{array}{l}\text { Distribution law } \\
\text { parameters }\end{array}$} & \multicolumn{3}{|c|}{$\begin{array}{l}\text { Value of Pearson's } \\
\text { chi-squared test }\end{array}$} & \multirow{2}{*}{$\begin{array}{c}\begin{array}{c}\text { Value of } \\
\text { Kolmogorov- } \\
\text { Smirnov test }\end{array} \\
\lambda_{\text {calc }} \\
\end{array}$} \\
\hline & $\alpha$ & $\beta$ & $f$ & $\chi_{\text {calc }}^{2}$ & $\chi_{\text {crit }}^{2}$ & \\
\hline \multicolumn{7}{|c|}{ Flash point } \\
\hline $\mathrm{D}_{11}$ & 149.16 & 89.71 & 4 & 8.848 & 9.49 & 0.672 \\
\hline $\mathrm{D}_{12}$ & 146.99 & 116.1 & 4 & 9.330 & 9.49 & 0.556 \\
\hline $\mathrm{D}_{13}$ & 145.54 & 134.3 & 3 & 7.510 & 7.82 & 0.971 \\
\hline $\mathrm{D}_{14}$ & 140.23 & 109.2 & 4 & 8.678 & 9.49 & 0.671 \\
\hline \multicolumn{7}{|c|}{ Organic acid content } \\
\hline $\mathrm{D}_{11}$ & 0.0079 & 2.899 & 2 & 0.609 & 5.99 & 0.228 \\
\hline $\mathrm{D}_{12}$ & 0.0085 & 2.766 & 4 & 5.851 & 9.49 & 0.586 \\
\hline $\mathrm{D}_{13}$ & 0.0094 & 2.812 & 5 & 9.364 & 11.1 & 0.693 \\
\hline $\mathrm{D}_{14}$ & 0.0096 & 2.986 & 3 & 1.939 & 7.82 & 0.401 \\
\hline $\mathrm{D}_{15}$ & 0.0223 & 1.725 & 2 & 4.943 & 5.99 & 0.699 \\
\hline \multicolumn{7}{|c|}{ BDV } \\
\hline $\mathrm{D}_{11}$ & 77.523 & 11.48 & 3 & 5.235 & 7.82 & 0.890 \\
\hline $\mathrm{D}_{12}$ & 71.499 & 11.24 & 4 & 8.207 & 9.49 & 0.893 \\
\hline $\mathrm{D}_{13}$ & 70.319 & 9.612 & 4 & 2.768 & 9.49 & 0.260 \\
\hline $\mathrm{D}_{14}$ & 69.855 & 8.038 & 4 & 9.229 & 9.49 & 0.754 \\
\hline \multicolumn{7}{|c|}{$\operatorname{tg} \delta$ at $90^{\circ} \mathrm{C}$} \\
\hline $\mathrm{D}_{11}$ & 0.237 & 1.605 & 3 & 1.485 & 7.82 & 0.459 \\
\hline $\mathrm{D}_{12}$ & 0.7926 & 2.055 & 2 & 2.710 & 5.99 & 0.509 \\
\hline $\mathrm{D}_{13}$ & 0.9018 & 1.283 & 3 & 7.286 & 7.82 & 0.760 \\
\hline $\mathrm{D}_{14}$ & 1.9017 & 1.745 & 4 & 0.685 & 9.49 & 0.181 \\
\hline \multicolumn{7}{|c|}{ Contamination content } \\
\hline $\mathrm{D}_{11}$ & 8.1592 & 2.457 & 2 & 3.024 & 5.99 & 0.709 \\
\hline $\mathrm{D}_{12}$ & 11.018 & 1.309 & 1 & 1.052 & 3.84 & 0.335 \\
\hline \multicolumn{7}{|c|}{ Water content } \\
\hline $\mathrm{D}_{11}$ & 5.2755 & 1.587 & 1 & 1.068 & 3.84 & 0.178 \\
\hline $\mathrm{D}_{12}$ & 10.762 & 2.407 & 5 & 3.305 & 11.1 & 0.301 \\
\hline
\end{tabular}

Table 7

Values of the Weibull distribution law parameters as well as the calculated and critical values of the Pearson and Kolmogorov-

Smirnov tests for the indicators of unusable oil in $110 \mathrm{kV}$ transformers and $330 \mathrm{kV}$ autotransformers

\begin{tabular}{|c|c|c|c|c|c|c|}
\hline \multirow{2}{*}{ 突 } & \multicolumn{2}{|c|}{$\begin{array}{c}\text { Distribution law } \\
\text { parameters }\end{array}$} & \multicolumn{3}{|c|}{$\begin{array}{l}\text { Value of Pearson's } \\
\text { chi-squared test }\end{array}$} & \multirow{2}{*}{$\begin{array}{c}\text { Value of } \\
\text { Kolmogorov- } \\
\text { Smirnov test } \\
\lambda_{\text {calc }}\end{array}$} \\
\hline & $\alpha$ & $\beta$ & $f$ & $\chi_{\text {calc }}^{2}$ & $\chi_{\text {crit }}^{2}$ & \\
\hline \multicolumn{7}{|c|}{$110 \mathrm{kV}$ transformer } \\
\hline \multicolumn{7}{|c|}{ Organic acid content } \\
\hline $\mathrm{D}_{21}$ & 0.1911 & 6.07 & 6 & 2.990 & 12.6 & 0.376 \\
\hline $\mathrm{D}_{22}$ & 0.2901 & 23.36 & 4 & 1.843 & 9.49 & 0.265 \\
\hline \multicolumn{7}{|c|}{ BDV } \\
\hline $\mathrm{D}_{2}$ & 29.459 & 7.311 & 4 & 3.162 & 9.49 & 0.228 \\
\hline \multicolumn{7}{|c|}{ Water-soluble acid content } \\
\hline $\mathrm{D}_{2}$ & 0.0401 & 3.155 & 5 & 3.009 & 11.1 & 0.420 \\
\hline \multicolumn{7}{|c|}{ Water content } \\
\hline $\mathrm{D}_{2}$ & 39.98 & 4.059 & 3 & 1.850 & 7.82 & 0.338 \\
\hline \multicolumn{7}{|c|}{$330 \mathrm{kV}$ autotransformer } \\
\hline \multicolumn{7}{|c|}{ Organic acid content } \\
\hline $\mathrm{D}_{2}$ & 0.1445 & 9.955 & 4 & 7.427 & 9.49 & 0.704 \\
\hline \multicolumn{7}{|c|}{$\mathrm{BDV}$} \\
\hline $\mathrm{D}_{2}$ & 42.576 & 23.25 & 4 & 2.763 & 9.49 & 0.323 \\
\hline \multicolumn{7}{|c|}{ Water content } \\
\hline $\mathrm{D}_{2}$ & 31.232 & 7.196 & 4 & 2.690 & 9.49 & 0.407 \\
\hline
\end{tabular}

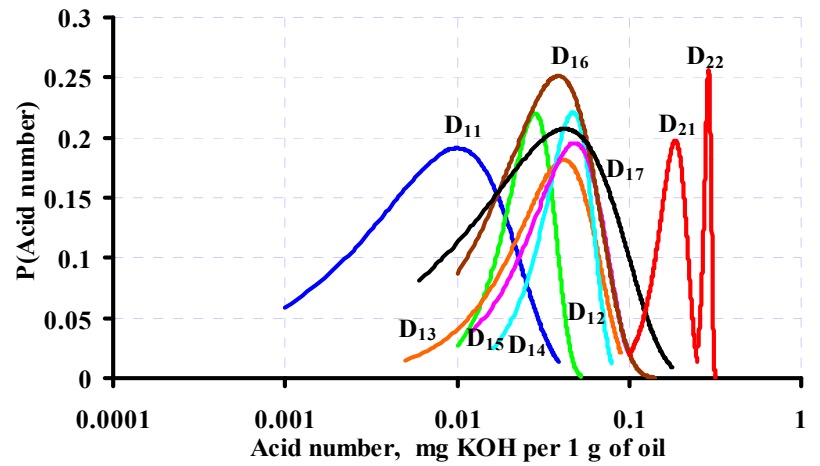

$a$

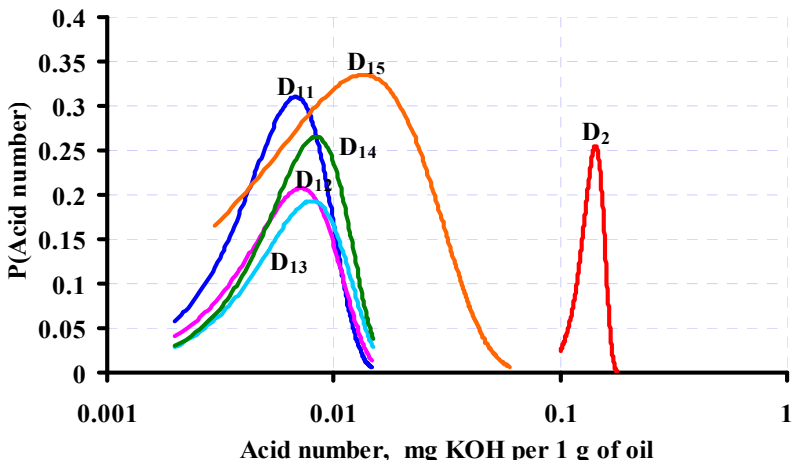

b

Fig. 3. Density functions of the theoretical distribution of organic acid content in oil for $110 \mathrm{kV}$ transformers $(a)$ and $330 \mathrm{kV}$ autotransformers $(b)$

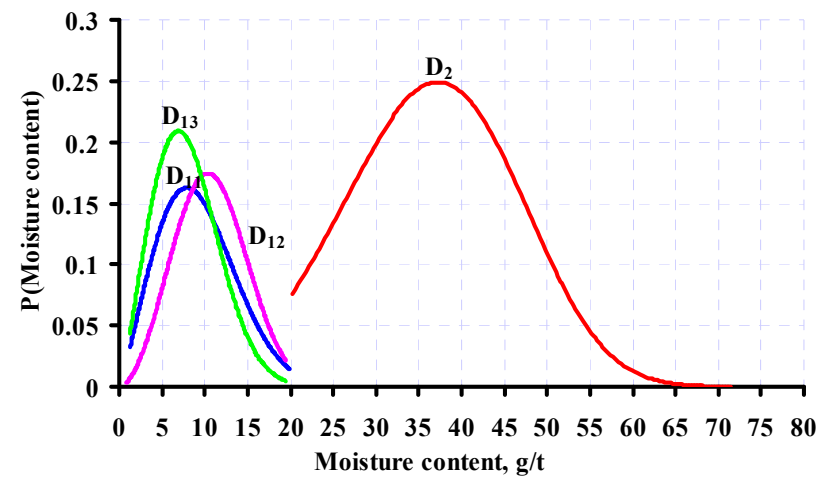
$a$

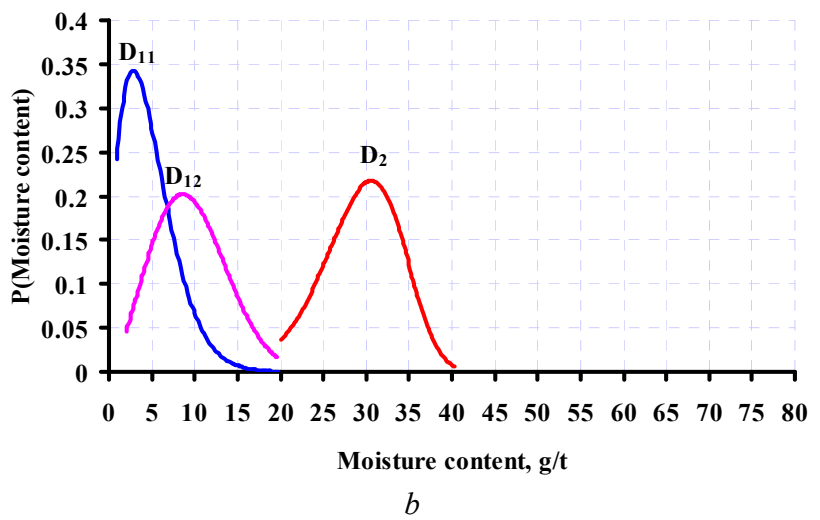

Fig. 4. Density functions of the theoretical distribution of water content in oil for $110 \mathrm{kV}$ transformers $(a)$ and $330 \mathrm{kV}$ autotransformers $(b)$ 


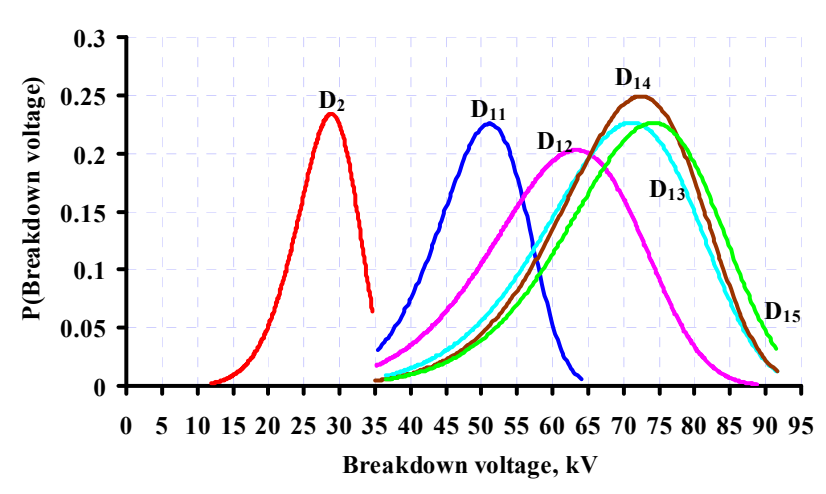

$a$

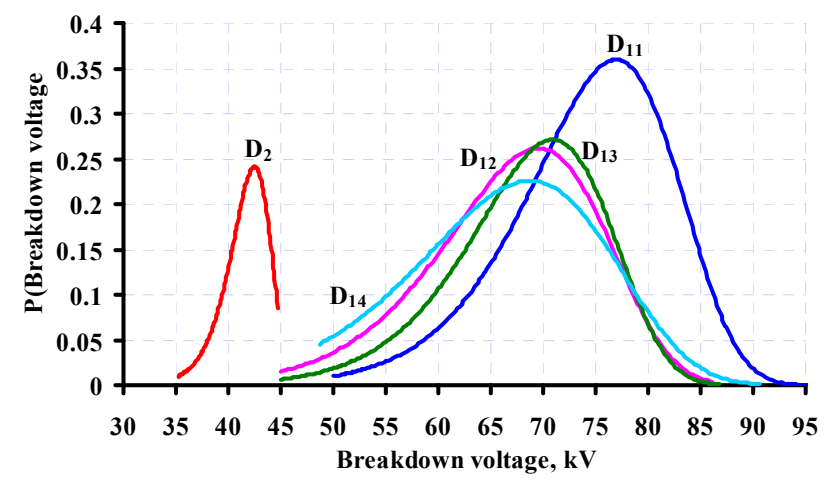

$b$

Fig. 5. Density functions of the theoretical distribution of the BDV in oil for $110 \mathrm{kV}$ transformers (a) and $330 \mathrm{kV}$ autotransformers $(b)$

\section{Conclusions.}

The analysis of the distribution laws of transformer oils showed that for both usable and unusable oil the distribution of oil indicators could be described by the Weibull distribution, which agrees well with the results of previously published studies. In the process of analysis, it was found that for the usable transformer oil, both for $110 \mathrm{kV}$ transformers and $330 \mathrm{kV}$ autotransformers there is a shift of mathematical expectations of the distribution density for different arrays of the same indicator. This indicates a different oil ageing degree which is caused by different oil service life, different operating temperatures of transformers as well as by the influence of structural materials. During the analysis, it was found that in $330 \mathrm{kV}$ autotransformers the oxidation reactions proceed with less intensity compared to $110 \mathrm{kV}$ transformers. This is evidenced by the presence of a shift between the distribution densities of some indicators of usable oil in $110 \mathrm{kV}$ transformers and $330 \mathrm{kV}$ autotransformers. It has been found that there is a significant shift between the mathematical expectations of the distributions of usable and unsuitable oil. This means that the residual life of oils in transformers analysed varies significantly. The obtained values of the parameters of the distribution laws of transformer oil indicators can be used in the development of models to estimate the service life of oils, as well as to predict and plan the timing of maintenance and repair of equipment, which will allow to carry out the transition to maintenance according to the real situation rather than the calendar plan. In addition, the presence of distribution law parameter values for indicators of oil with different states allow to estimate the state of transformer oils using likelihood ratios, which can significantly reduce the risks of making wrong decisions.

Conflict of interests. The authors declare no conflicts of interest.

\section{REFERENCES}

1. N'cho J., Fofana I., Hadjadj Y., Beroual A. Review of Physicochemical-Based Diagnostic Techniques for Assessing Insulation Condition in Aged Transformers. Energies, 2016, vol. 9, no. 5, p. 367. doi: https://www.doi.org/10.3390/en9050367.

2. Mehmood M., Nazir M., Li J., Wang F., Azam M. Comprehensive Investigation on Service Aged Power Transformer Insulating Oil After Decades of Effective Performance in Field. Arabian Journal for Science and Engineering, 2020, vol. 45, no. 8, pp. 6517-6528. doi: https://www.doi.org/10.1007/s13369-020-04559-7.

3. Rengaraj R., Venkatakrishnan G.R., Moorthy P., Pratyusha R., Ritika, Veena K. Transformer Oil Health Monitoring Techniques-An Overview. Advances in Intelligent Systems and Computing, 2020, pp. 135-154. doi: https://www.doi.org/10.1007/978-981-15-5029-4 12. 4. Tyuryumina A., Batrak A., Sekackiy V. Determination of transformer oil quality by the acoustic method. MATEC Web of Conferences, 2017, vol. 113, p. 01008. doi: https://www.doi.org/10.1051/matecconf/201711301008.

5. Leong Y., Ker P., Jamaludin M., Nomanbhay S.M., Ismail A., Abdullah F., Looe H., Lo C. UV-Vis Spectroscopy: A New Approach for Assessing the Color Index of Transformer Insulating Oil. Sensors, 2018, vol. 18, no. $7, \quad$ p. 2175 . doi: https://www.doi.org/10.3390/s18072175.

6. Kang S.B., Kim W.-S., Chung D.C., Joung J.M., Kwak M.H. Degradation diagnosis of transformer insulating oils with terahertz time-domain spectroscopy. Journal of the Korean Physical Society, 2017, vol. 71, no. 12, pp. 986-992. doi: https://www.doi.org/10.3938/jkps.71.986.

7. Alshehawy A.M., Mansour D.A., Ghali M., Rezk A. Evaluating the impact of aging in field transformer oil using optical spectroscopy techniques. 2017 IEEE 19th International Conference on Dielectric Liquids (ICDL), 2017, pp. 1-4. doi: https://www.doi.org/10.1109/ICDL.2017.8124626.

8. Degeratu S., Rotaru P., Rizescu S., Danoiu S., Bizdoaca N.G., Alboteanu L.I., Manolea H.O. Condition monitoring of transformer oil using thermal analysis and other techniques. Journal of Thermal Analysis and Calorimetry, 2015, vol. 119, no. 3, pp. 1679-1692. doi: https://www.doi.org/10.1007/s10973-014-4276-3.

9. Zhao Y., Qian Y., Li L., Zheng Z., Wang Q., Zhou Y. Research on Transformer Oil Multi-frequency Ultrasonic Monitoring Technology Based on Convolutional Neural 
Network. 2019 IEEE 20th International Conference on Dielectric Liquids (ICDL), 2019, pp. 1-5. doi: https://www.doi.org/10.1109/ICDL.2019.8796733.

10. Srividhya V., Babu J.S., Sujatha K., Veerendrakumar J., Aruna M., Shafiya S., SaiKrishna, Anand M. Determination of Breakdown Voltage for Transformer Oil Testing Using ANN. Advances in Intelligent Systems and Computing, 2021, pp. 443-452. doi: https://www.doi.org/10.1007/978-981-33-6981-8_35.

11. Singh H., Singh J. Enhanced optimal trained hybrid classifiers for aging assessment of power transformer insulation oil. World Journal of Engineering, 2020, vol. 17, no. 3, pp. 407-426. doi: https://www.doi.org/10.1108/wje-11-2019-0339.

12. Gautam L., Kumar R., Sood Y.R., Identifying Transformer Oil Criticality Using Fuzzy Logic Approach. 2020 IEEE Students Conference on Engineering \& Systems (SCES), 2020, pp. 1-6. doi: https://www.doi.org/10.1109/SCES50439.2020.9236724.

13. Milosavljevic S., Janjic A. Integrated Transformer Health Estimation Methodology Based on Markov Chains and Evidential Reasoning. Mathematical Problems in Engineering, 2020, vol. 2020, pp. 1-12. doi: https://www.doi.org/10.1155/2020/7291749.

14. Surya Subaga I.G., Manuaba I.B.G., Sukerayasa I.W. Analisis Prediktif Pemeliharaan Minyak Transformator Menggunakan Metode Markov. Jurnal SPEKTRUM, 2019, vol. 6, no. 4, pp. 96-101. (Ind). Available at: https://ojs.unud.ac.id/index.php/spektrum/article/view/553 35/32753 (Accessed 22 May 2021).

15. Rexhepi V., Nakov P. Condition assessment of power transformers status based on moisture level using fuzzy logic techniques. Journal of Mechatronics, Electrical Power, and Vehicular Technology, 2018, vol. 9, no. 1, pp. 17-24. doi:

https://www.doi.org/10.14203/j.mev.2018.v9.17-24.

16. Chantola A., Sharma M., Saini A. Integrated Fuzzy Logic Approach for Calculation of Health Index of Power Transformer. 2018 Second International Conference on Inventive Communication and Computational Technologies (ICICCT), 2018, pp. 1045-1050. doi: https://www.doi.org/10.1109/ICICCT.2018.8473316.

17. Shutenko O., Ponomarenko S. Diagnostics of Transformer Oils Using the Multiple Linear Regression Model 2020 IEEE Problems of Automated Electrodrive. Theory and Practice (PAEP), 2020, pp. 1-6, doi: https://www.doi.org/10.1109/PAEP49887.2020.9240875.

18. Abdi S., Harid N., Safiddine L., Boubakeur A., Haddad A. The Correlation of Transformer Oil Electrical Properties with Water Content Using a Regression Approach. Energies, 2021, vol. 14, no. 8, p. 2089. doi: https://www.doi.org/10.3390/en14082089.

19. Gouda O., El Dein A. Prediction of Aged Transformer Oil and Paper Insulation. Electric Power Components and Systems, 2019, vol. 47, no. 4-5, pp. 406-419. doi: https://www.doi.org/10.1080/15325008.2019.1604848.

20. IEC 60422. Mineral insulating oils in electrical equipment - Supervision and maintenance guidance. 2012.
21. SOU-N EE 43-101:2009. Adoption, application and use of transformer oils. Quality assessment standards. Kyiv, 2018. (Ukr).

22. Davidenko I.V., Egorov A.A. Determination of Criteria for Assessing the Oil Quality of Current Transformers Type TFZM 110 kV. 2020 IEEE Conference of Russian Young Researchers in Electrical and Electronic Engineering (EIConRus), 2020, pp. 12041207.

doi:

https://www.doi.org/10.1109/EIConRus49466.2020.9039

$\underline{527}$.

23. Azis N., Zhou D., Wang Z.D., Jones D., Wells B., Wallwork G.M. Operational condition assessment of inservice distribution transformers. 2012 IEEE International Conference on Condition Monitoring and Diagnosis, 2012, pp. 1156-1159. doi: https://www.doi.org/10.1109/CMD.2012.6416364.

24. Davidenko I., Egorov A. Development of an integral criterion for evaluating the degree of aging of transformer oils. IOP Conference Series: Materials Science and Engineering, 2020, vol. 950, p. 012005. doi: https://www.doi.org/10.1088/1757-899x/950/1/012005.

25. Shutenko O. Determine the boundary value of the concentration of gases dissolved in oil of method minimum risk. 2017 IEEE First Ukraine Conference on Electrical and Computer Engineering (UKRCON), 2017, pp. 468-472. doi: https://www.doi.org/10.1109/UKRCON.2017.8100533.

26. Shutenko O., Zagaynova A., Serdyukova G. Determining the maximally permissible values for the indicators of insulation of sealed entrance bushings with a voltage of $110 \mathrm{kV}$ using the method of minimal risk. Eastern-European Journal of Enterprise Technologies, 2018, vol. 5, no. 8 (95), pp. 6-15. doi: https://www.doi.org/10.15587/1729-4061.2018.142185.

27. Mohd Selva A., Azis N., Shariffudin N.S., Ab Kadir M.Z.A., Jasni J., Yahaya M.S., Talib M.A. Application of Statistical Distribution Models to Predict Health Index for Condition-Based Management of Transformers. Applied Sciences, 2021, vol. 11, no. 6, pp. 2728. doi: https://www.doi.org/10.3390/app11062728.

28. Tsuboi T., Takami J., Okabe S., Inami K., Aono K. Aging effect on insulation reliability evaluation with Weibull distribution for oil-immersed transformers. IEEE Transactions on Dielectrics and Electrical Insulation, 2010, vol. 17, no. 6, pp. 1869-1876. doi: https://www.doi.org/10.1109/TDEI.2010.5658240.

29. Birger I.A. Technical diagnostics. Moscow, Mashinostroenie Publ., 1978. 240 p. (Rus).

30. Davidenko I.V. Determination of allowable values of controlled parameters of oil-filled equipment on the basis of an array of observed data. Elektrichestvo, 2009, no. 6, pp. 10-21. (Rus). Available at: https://elibrary.ru/download/elibrary_12880537_3589719 5.pdf (Accessed 22 May 2021).

31. Davidenko I.V. Investigation of indicators describing the operational state of oil-filled bushings, using mathematical statistics. University news. NorthCaucasian region. Technical sciences series, 2006, no. 15, pp. 31-33. (Rus). 
32. Shutenko O., Zagaynova A., Serdyukova G. Analysis of distribution laws of insulation indicators of highvoltage oil-fillled bushings of hermetic and non-hermetic execution. Technology audit and production reserves, 2018, vol. 4, no. 1 (42), pp. 30-39. doi: https://www.doi.org/10.15587/2312-8372.2018.140873.

33. Lipstein R.A., Shakhnovich M.I. Transformer oil. Moscow, Energoatomizdat Publ., 1983. 296 p. (Rus).

34. Vasilevskij V.V. Assessment of the resource consumption of oil-filled power transformer paper insulation based on updated aging integral. Electrical Engineering \& Electromechanics, 2015, no. 1, pp. 16-19. (Rus). doi: https://www.doi.org/10.20998/2074272x.2015.1.03.

35. Poliakov M.A., Vasilevskij V.V. Evaluation of power transformer insulation residual life based on its individual life cycle characteristics. Electrical Engineering \& Electromechanics, 2014, no. 3, pp. 38-41. (Rus). doi: https://www.doi.org/10.20998/2074-272x.2014.3.07.

36. Shutenko O., Ponomarenko S. Analysis of the Impact of Power Transformer Loading on the Transformer Oil Aging Intensity. 2020 IEEE KhPI Week on Advanced
Technology (KhPIWeek), 2020, pp. 76-81. doi: https://www.doi.org/10.1109/KhPIWeek51551.2020.9250 159 .

37. Shutenko O.V., Baklay D.N. Planning of experimental research in power engineering. Methods of Processing of Experimental Data. Kharkiv, NTU «KhPI» Publ., 2013. 268 p. (Rus).

38. Rinne H. The Weibull distribution. Boca Raton, CRC Press, 2009. 808 p.

Received 15.07.2021

Accepted 24.09.2020

Published 26.10.2021

O. Shutenko ${ }^{1}$, PhD, Associate Professor,

S. Ponomarenko ${ }^{1}$, PhD Student,

${ }^{1}$ National Technical University «Kharkiv Polytechnic

Institute»,

2, Kyrpychova Str., Kharkiv, 61002, Ukraine,

e-mail: o.v.shutenko@gmail.com,

PonomarenkSerhii@gmail.com (Corresponding author)

How to cite this article:

Shutenko O., Ponomarenko S. Analysis of distribution laws of transformer oil indicators in 110-330 kV transformers. Electrical Engineering \& Electromechanics, 2021, no. 5, pp. 46-56. doi: https://doi.org/10.20998/2074-272X.2021.5.07. 